\title{
THE ECONOMIC CRISES HAVE REPLACED THE WAR BETWEEN THE MEGA WORLD POWERS
}

\author{
Luca DIACONESCU * \\ University of Oradea, Doctoral School of geography, 1st, Universității St., 410087, Oradea, Romania, \\ e-mail: diaconesculuca@yahoo.ro
}

Citation: Diaconescu, L. (2020). The Economic Crises have Replaced the War between the Mega World Powers. Revista Română de Geografie Politică, 21(1), 20-26. https://doi.org/10.30892/rrgp.221103-335

\begin{abstract}
The rise of a new economic power brings with it the extension of influence on the globe and the status of equal with the old powers, but for this, the old ones must give up some of their own interests. These global geopolitical changes were made in the past by wars, being replaced nowadays by economic crises.
\end{abstract}

Key words: century asian, west, bank loans, speculate

\section{INTRODUCTION}

The economic and financial influence of the world has been found for over a century in two global regions, namely Europe (last 500 years) and North America (last 100 years). In the last half century, after a long period of regression and the global economic pole of East Asia reappears. However, three world mega-centers are far beyond the capacity to support the Earth, the less productive regions, lacking their own dominant financial institutions and with dependence on the North Atlantic economic nucleus, being hit by the economic crises that bring them back decades ago, canceling speculation and economy based on bank loans. This being the role of the Asian crisis of 1997, which has hit economic "tigers" and "dragons": Japan, South Korea, Philippines, Thailand, Indonesia and so on, ie states whose economy has been booming with overestimations, speculation and loan provided by US banks (the International Monetary Fund established in 1945 and the World Bank in 1944, both based in the US capital, Washington), in a policy of stopping the expansion of communist influence, measures canceled after 1990.

But the next two economic crises seem to bypass Asia, these states becoming in time the "workshop of the world", building on a healthy economy without over-speculating or bank loans and building on their after crisis of 2008-2012, the own ,IMF and World Bank" Asian in the presence of banks: 
Asian Investment and Infrastructure Bank (AIIB) established between 2013 and 2016 with headquarters in Beijing in China (to which the US has sharply opposed being dissatisfied when old allies such as Australia or the United Kingdom over Germany, France, Italy or the Netherlands, became members, after followed by 2017 to include countries such as: Canada, Argentina or Belgium) and the New Development Bank (NDB) formed by the BRICs (Brazil, Russia, India, China, South Africa). between 2014-2015, based in China, Shanghai (Goh, 2016; Mazilu, 2008; King, 2016).

Both the crisis of 2008-2012 and the ongoing crisis of 2020 -?, Predicted by many years but aggravated by the infestation of the population with a new pandemic called coronavirus, very contagious (with rates of mortality lower or equal with the local influenza, what happens every winter season, but with draconian measures to isolate the population that will hasten the death of a large number of people in different stages of other diseases, due to lack of access to water, food and medical care), they seem to economically attacks especially the powers lacking in their own banking systems that regulate the exchange rates in their favor (Southern and Eastern Europe such as: Italy, Spain, Romania and so on) but not the hard core of Europe (France, Germany, Great Britain, Benelux countries). These protected states will survive economically in the next decade, with the help of the specialized workforce to leave the southern and eastern states and to take the path of northwestern Europe, as well as filling the economic and commercial gap left vacant after hundreds of thousands of companies went bankrupt, from Europe sacrificed. From the hard core of Europe, there are states that are not affected at present, even though most tourists, the largest ports and airports are concentrated here, states that have not been affected by the fall of the banking system since the crisis of 2008-2012, even though they have all the major European banks, countries that do not struggle with the global warming that they promote with such fervor in the southern and eastern states and that trade non-stop with countries such as: Russia, China, Iran or Algeria, although they limit the trade of the other states to these one-party countries.

In the current geopolitical picture, the question is whether the Earth economy will continue in the same direction, so that in the next two world crises that will most likely take place around 2030 and 2040, the European economic nucleus will also decline, following as in the following economic crises in around the 2050s, 2060s and 2070s the dollar was extinguished (when the US is likely to be overtaken by the Indian economy), and the financial, military and technological megacapacity of the United States is far outpaced by the new power concentrations in Asia, by the end of the 21st century, the crises to hit East Asia (China, Korea and Japan already after many decades of demographic decline and population aging) when over $60 \%$ of the world's population will be concentrated in the southern half of Asia and Sub-Saharan Africa, surrounding the world new epicenter, of the Indian Ocean (Diaconescu, 2020; Diaconescu et al., 2019).

\section{READING. WHY ECONOMIC CRISES ARE ENCOURAGED AND THE FINANCIAL BOOM NON-PRODUCTION BASED?}

\section{Bank Loans}

To understand what a bank loan economy means, we need to remember the situation of Eastern European states before the 2008 crisis, in which many 
businessmen with loans helped create villas and prosperity neighborhoods until the day when the bank refused to grant loans, then the economic crisis began. Theoretical situation can be as follows: in a community, no family earns enough and does not have the ability to build an upstairs house in the next 10-15 years. An entrepreneurial person obtains a bank loan with monthly installments that extend over the next 30-40 years, even if the age of the businessman is already over 30-40 years. With the money he builds two houses that he sells for a double amount, to two families who do not even own the money, but use a bank loan each for 30-35 years each. With this money, the businessman builds another 3 houses, the building materials or the workers becoming more greedy because "the profits from the sale of the houses are generated largely by the their work". The trend appears in the community and the number of those who do not produce enough money but want a house bought with borrowed money increases, and the following houses will be sold at a price of 4-5 times higher than the production price, during which time they fall and interest in quality, buyers being pleased to take one of the few homes for sale. All these transactions do not imply the possession of certain specializations or abilities, being a rather permissive business. Our man still builds another 10-13 houses, along with him appearing other new builders with money borrowed from the bank, who want to follow his example, also increasing the number of people interested in buying one of the new houses, all with bank loans. Workers are becoming increasingly sought and increasing the asking price for the work performed, becoming more and more little serious in the perspective of overburdening, and appear the food stores, for building materials, tools and tools, car workshops, private schools and hospitals, taxi companies and so on, all the features opulence settles fast until a day when banks stop lending and the economy returns to its previous status. Nobody builds anymore, nobody buys even at of a quarter at the low prince, small businesses don't go anymore, people run out of jobs and bank rates become unbearable to pay. The bank begins foreclosure by becoming the new owner of the houses, selling further to recover its money, which is the story of many of the numerous neighborhoods of villas that appeared on the outskirts of the Eastern European cities between 2000 and September 15, 2008, when the banks stopped lending, when it occurs the beginning of the economic crisis.

\section{Speculate}

Firms appear, develop and regress, when they either take vital measures to avoid failure and change strategy, or they are bought by other companies or go bankrupt. But in addition to bank loans that artificially extend the existence of a company, there is also speculation, in which the economic company promises more than it can offer, based on lies. One of the hundreds of thousands of examples in the western world is the Bre-x business, whereby a bankrupt Canadian company, with borrowed money, earns the rights to exploit possible gold deposits on the Borneo island of Indonesia. By powdering the earth samples with gold before they are sent to laboratories, the company speculates that a huge gold mountain of a volcano has fallen into the interior, claiming that possible gold reserves are worth between $\$ 25$ and $\$ 50$ billion, damaging the large mass of businessmen who are in a hurry to buy shares in the wonderful company, with over 3 billion US dollars. Thus, th was dying company increased its value by $100,000 \%$ in just three years, until in 1997 it announced its bankruptcy (Fortune, 2010, p. 112-119). Cases of bankrupt companies that 
resort to such speculative methods to multiply their unmerited profit, are found in abundance throughout the western world, adding to them many more other undiscovered scams.

\section{MONEY MADE WITHOUT A REAL PRODUCTION BASE}

In the world, the sum of the fictitious money is 3 times greater than the real money, and the number of those who make money playing the stock market or other activities in which they practically do not produce anything is constantly increasing. Thus, the same company with the same number of employees, production and work base, can value on the stock exchange and 50$200 \%$ more only based on a statement made but also decrease by $20-50 \%$ also based on an inappropriate word said by one of the chiefs.

Another situation of false imitation of success and unmerited enrichment lies in the money of life insurance and goods, there are more and more cases in the western world when people unable to succeed through honest work, destroy their own car, set fire to the company or home or they kill the race horses, to collect the money from the insurance, there are countless cases when people have resorted even to the crime, sometimes degenerating into the business of their life, through which they lived their life in luxury and wealth only by killing the people they previously insured. , as the cases: Aurore Martin and Peter Schmitt, Issac Aguigui, Mark Edward Lundy, Karl Karlsen, Uloma Curry-Walker et al., besides many other cases that have not been discovered.

These do not seem to be situations worth dealing with in a work of geopolitics and economics. But these are cases that in their time raised the economy of the countries from which they came, being presented as models of success of progress, being non-productive people, unable to help them raise the real production, but who had and ran exorbitant amounts of money, amounts that, over time, the banks covered with banknotes out of the market and with a favorable exchange rate that unjustifiably raised the financial market. These amounts are not allowed to business people even if they work and produce large quantities of goods, as long as they are in countries with weak currencies and lacking their own mega-banks to run the exchange rate in their favor, such as countries in: Asia, Latin America, Africa or Eastern Europe.

\section{FORECAST OF THE FOLLOWING ECONOMIC CRISES AND WHAT CHANGES GEOPOLITICS ARE FOLLOWED}

The rise of a new global mega-region leads to the weakening of an already existing but less productive one. The new space of power wants to be part of the main decisions, a recognized influence and a part of the regions in the spheres of control of the already existing powers, from which they come into conflict with them, the old powers wanting to maintain their supremacy. In history, whenever a new world economic power has appeared, there have been preceded by wars between them and the old powers.

Currently, centuries-old centers of world power are concentrated in Europe and the US, and new areas of progress and wealth accumulation in industrialized Asian states. In order to delay the surrender of power, the western states artificially maintain their economic status with the help of the massive loans and financing they make in their own economy, maintaining productions mainly with the help of subsidies, without having a real and competent productive support. These actions extend over periods of about 10 years, after which economic crises 
decline production to real values similar to the power existing a decade ago. The fluctuation of the speculative economy and bank financed, resembles the small dams built on the erosive rivers by their clogging, in which the water is artificially maintained at a level of stagnation even though the relief of the valley goes down, after which a cascade follows to return to the real altitude level. Why these the erosion dams are rarer, the cascades are higher, causing strong water drops. Like them, the dams that keep the water at the floating level are reflected in the economy through the bank loans that delays the decline of an less productive market, and the cascades through which the water of the river returns to the level of the river represent in the financial environment means the economic crises, of what they are rarer, from which they become more severe.

The most affected states are those that do not have their own mega-banks to give their favorable exchange rate, the production base has been replaced by the recreational, speculative, green, natural economy and so on, where there has been no price on the real production, and do governments have no authority over their own countries, located on the outskirts of the western world, these being the states of Latin America and southern and eastern Europe, affected by the economic crisis of 2008-2012, the current crisis of 2020-? and probably the next global crisis to take place around 2030. These declines will announce the narrowing of the western core and will be severely affected by North-West Europe (Germany, France, Great Britain, Holland and so on) to the following economic crises in around 2030, 2040 and 2050 (years when the European Union will be economically overtaken by India and $200 \%$ by China, by nominal GDP), followed by crises in the 2060s and 2070s (maybe 2050s) when the US will suffer after its economic overcoming by the new powers, similar to the European Union, to end the Europeanization and Americanization of the planet for the next many decades or centuries, fulfilling the prediction of the geopolitics of the last 6-7 decades, that the current 21 st century will be the Century Asian.

Table 1. The economic evolution of the world between 1980 and 2060, in trillions of dollars (Gross Domestic Product nominal)

(Source: author estimates and data processed by: Peptenatu et al, 2005; Ayres, 2017; Khanna, 2019; Reilly, 2011)

\begin{tabular}{|c|c|c|c|c|c|c|}
\hline Super powers & $\begin{array}{c}1980 \\
\text { (Trillion US } \\
\text { dollars) }\end{array}$ & 1990 & 2000 & 2018 & Estimare 2030 & Estimare 2060 \\
\hline $\begin{array}{c}\text { United States of } \\
\text { America }\end{array}$ & 2,700 & 5,700 & 10,000 & 20,000 & $26,000-33,000$ & $50,000-70,000$ \\
\hline Russia & 1,200 (U.R.S.S) & 2,700 (U.R.S.S) & 0,300 & 1,700 & $2,500-3,000$ & $5,000-7,000$ \\
\hline European Union & $\begin{array}{c}6,000 \\
\text { UE-9 state }\end{array}$ & $\begin{array}{c}6,400 \\
\text { UE- } 12\end{array}$ & $\begin{array}{c}8,500 \\
\text { UE- } 15\end{array}$ & $\begin{array}{c}19,000 \\
\text { UE- } 28\end{array}$ & $23,000-30,000$ & $40,000-60,000$ \\
\hline Japan & 1,000 & 3,000 & 5,000 & 5,000 & $6,000-7,000$ & $9,000-13,000$ \\
\hline China & 0,180 & 0,400 & 1,200 & 14,000 & $28,000-35,000$ & $100,000-150,000$ \\
\hline India & 0,180 & 0,300 & 0,500 & 3,000 & $7,000-10,000$ & $40,000-90,000$ \\
\hline World & 11,000 & 22,000 & 33,000 & 87,000 & $140,000-170,000$ & $320,000-530,000$ \\
\hline
\end{tabular}

If we talk about the sum of money at the parity of purchase (PPP GDP), that is, the real economy, China already exceeds the US or European Union's power by $40 \%$, and India by $230 \%$ Germany's power. When it comes to nominal GDP, ie the amount resulting from converting the money from these countries into US dollars (depending on the currency quotations set by the Western-owned financial system that benefits the western states), China will reach the US by 2026, and India will surpassed Germany after 2024 (Frankopan, 2018; Maçães, 2018; McGregor, 2017). Analyzing the global economic situation of North Atlantic power compared to Asia + Russia, we find a clear economic superiority in favor of Europe and the 
USA in the past, the ratio between them and the new powers being (in trillions of US dollars) in the: 1980 s 5,7 to 2.5 trillion, from 1990 to 12.1 to 6.4 trillion, and from 2000 to 18.5 to 7.0 trillion, when the main powers of Asia plus Russia held only $38 \%$ of the sea western power. During this period, many of the states of Asia were after only 2-3 decades of independence, without their own banking systems and with a currency national world quoted at lower rates compared to the US dollar, British pound, German mark, French franc or Italian pound (Herman and Grama, 2018; Kennedy, 2017; Stuart-Fox, 2003).

By 2018, the East is recovering substantially in its competition with the West, the nominal GDP ratio in favor of the European Union and the US being 39.0 to 23.7 trillion US dollars. With healthy economic output and its own AIIB and NDB financial systems set up over the last decade, which is in direct competition with Western IMF and World Bank banks already existing for 7 decades, the new economic powers hope for a bright future in which difference between them and the West will decrease until it is reversed in their favor. In 2030 a difference between North-Atlantic and Asian powers of 49-63 to 43-55 trillion US dollars is foreseen when the balance will tend to equalize, and for 2060 a ratio of 90-130 to 154-260 trillion US dollars US, when it expects the 3 powers from Asia plus Russia to overtake their old rivals US and European Union, by over $80 \%$.

\section{WHAT TO DO?}

The United States emphasized the army and the position of world leader, and the European Union on the rule of law and the fight against global warming (Mody, 2018). These global mega-centers, after several centuries of permanent industrialization, felt that the time had come to give up the production capacities they left to the attribution of the states of Asia, while the western countries with the help of the world banking system that they dominate him as well as the economic speculator, they thought that they would hold the world primacy for a long time. Considering that "work is no longer for you", Europeans and Americans focused on spending ever larger amounts of unpaid money, discouraging investment in production. These powers no longer want constructions of: energy centers, highways, schools, hospitals, research centers or the production of finished products, nor do they come with sound investments in the partner states, and only defense and armament procurement policies, greening, increasing rights and funding to institutions that define the "rule of law" or the implementation of strategic partnerships.

The faster the awareness, the further the collapse will be delayed or even avoided. But in the current situation, the Asian states have seized after the 20082012 crisis more and more of the pro-European countries (Turkey, Russia, Greece) and pro-US (Brazil, Argentina, Persian Gulf states), and after the current crisis in 2020-?, Countries from the Mediterranean (Italy, Spain) and the Caribbean (Costa Rica, Nicaragua, Venezuela) will be Asianization. While the US calls for $2 \%$ of GDP for defense by increasingly selling arms to NATO partner states, and the European Union implements a a prosecutor of attorney at European level and the Green Deal project which will close the last European production bases, all for the protection of nature and wild animals, Asia is aiding the hurricane-hit states of Central America or coronavirus from South and Eastern Europe, emphasizing the urgent needs of the inhabitants of these territories on the outskirts of global mega-centers. With each future crisis it seems that the European and North American economic nucleus will shrink, leaving room for planetary Asianization and the new era of the $21^{\text {st }}$ century, which will be the Century of Asia. 


\section{CONCLUSIONS}

It was when the people of the Asian states worked hard to produce goods for the West but struggled in poverty because they did not have their own banking systems, while Westerners planned the enrichment without work, to cover the strong currencies and financial systems developed in their states, tends to disappear. Asia became the workshop of the world doing the hard work and the European Union, the United Kingdom and the United States became powers concerned with: defense, global primacy, global warming and the rule of law, covering their expenses with the help of strong currencies and the currency exchange rate which dictates with the help of the big world banking systems that they own. After the establishment of its banks, after the economic crisis 20082012, Asia gives more and more value to the real economy it has developed, leaving less room for maneuver, the speculative economy created with the help of loans, which has developed in the old world powers, these being increasingly hit by the economic crises that will bring them to the real financial situation.

\section{REFERENCES}

Ayres, A. (2017). Our time has come: How India is making its place in the world. Oxford University Press. Diaconescu, L. (2020). Island of the World. Moving the World strategic center from Heartland to the Indian Ocean. Revista Română de Geografie Politică, 22(1), 1-8.

Diaconescu, L., Nichituț, N., Lung, M.S. (2019). Colossi-Crumbs in the year 1900 - Colossi-Colossi in the year 2100. Transfer of demographic-economic predominance from Eurasia to Afroamerica. Revista Română de Geografie Politică, 21(2), 50-59.

Frankopan, P. (2018). The New Slik Roads: The Present and Future of the World, Bloomsbury Publishing House, Londra, U.K.

Goh, E. (Ed.). (2016). Rising China's influence in developing Asia. Oxford University Press.

Herman, G.V., Grama, V. (2018). Geographical aspects of space-time evolution of independent states. Revista Română de Geografie Politică, 20(2), 49-56.

Kennedy, P. (2017). The Rise and Fall of the Great Powers: Economic Change and Military Conflict from 1500-2000, William Collins Publishing House, New York, U.S.A.

Khanna, P. (2019). The Future is Asian: Global Order in the Twenty-first Century, Weidenfeld \& Nicolson Publishing House, Londra, U.K.

King, A. (2016). The end of alchemy: money, banking and the future of the global economy, Little Publishing House, Brown Book Group, U.K., U.S.A.

Maçães, B. (2018). The dawn of Eurasia: On the Trail of the New World Order, Penguin Publishing House, Londra, U.K.

Mazilu, M.E. (2008). To be or not to be afraid of globalization in Journal?, Analele Universității din Craiova, Seria Geografie, 11, 87-91.

McGregor, R. (2017). Asia's reckoning: The struggle for Global dominance, Penguin Publishing House, Londra, U.K.

Mody, A. (2018). Euro Tragedy: A drama in nine acts, Oxford University Press Publishing House, U.K.

Peptenatu, D., Drăghici, C., Cepoiu, L.A. (2005). Geografie economicã mondială, Ediția a II-a (World Economic Geography, 2 ${ }^{\text {nd }}$ Edition II), Editura Universitară, București.

Reilly, J. (2011). Strong Society, Smart State: The rise of public opinion in China's Japan policy, Contemporany Asia in the World, Columbia University Press Publishing House, New York, U.S.A.

Stuart-Fox, M. (2003). A short history of China and Southeast Asia: tribute, trade and influence, Allen $\&$ Unwin Publishing House, Australia.

*** Fortune (2010). Scandal! Escrocherii care au zguduit lumea (Scandal! The scams that shook the world), Editura Litera International, București.

Submitted:

December 20, 2019
Revised:

March 04, 2020
Accepted and published online: April 29, 2020 